\title{
Artigo
}

\section{Politics versus Policy: Is Police Politicization a Threat to Democracy in Brazil?}

\author{
Política contra Política: \\ A Politização da Polícia é uma ameaça \\ à democracia no Brasil?
}

\author{
Anthony W. Pereira \\ Director, Brazil Institute of King's College - London
}

\begin{abstract}
The reform of the public security institutions (especially the police, courts, and prisons) has become a major political issue in much of contemporary Latin America. In Brazil, some police analysts argue that police "politicization" distorts policing and ultimately threatens democracy. This article explores this claim. Drawing on qualitative interviews with officials involved in public security in Recife (Pernambuco, Brazil) it distinguishes between two variants of the politicization thesis. It concludes by arguing that if politicization is taken to mean excessive party control over the Executive branch, including the police, then it does not threaten democracy. On the contrary, innovative reforms are often driven by party political competition.
\end{abstract}

Keywords: Democracy; Democratization; Police; Public Security; Politicization; Police Reform.

Resumo: A reforma das instituições de segurança pública (especialmente a polícia, os tribunais e as prisões) tornou-se uma importante questão política em grande parte da América Latina contemporânea. No Brasil, alguns analistas da polícia afirmam que a "politização" da polícia distorce o policiamento e, finalmente, ameaça a democracia. Este artigo explora esse objetivo. Baseando-se em entrevistas qualitativas realizadas com os funcionários envolvidos na segurança pública em Recife (PE, Brasil), este artigo distingue entre duas variantes da tese de politização. Conclui argumentando que, se por politização entende-se o excessivo controle do partido sobre o Poder Executivo, incluindo a polícia, então a politização da polícia não ameaça a democracia. Pelo contrário, reformas inovadoras são frequentemente impulsionadas pela competição político-partidária.

Palavras-chave: Democracia; democratização; Polícia; Segurança Pública; politização; Reforma da polícia. 


\section{Introduction}

The reform of public security policy has become a major political issue in Latin America. The organization, procedures, and relations between those state agencies most responsible for "law and order" - the police, prosecutors, judiciary, and prisons, as well as social services - are coming under increasing scrutiny, as politicians and the public demand change. The reform of these state agencies is crucial to the quality of democracy in the region (O'DONNELL; CULLEL; IAZZETTA, 2004). An especially acute problem is inequality in the provision of security - for example, urban slum dwellers are relatively unprotected from violence practiced by both state and non-state actors. As Dirk Kruijt writes, the "phenomenon of social exclusion-cum-violence shared by the masses of the urban poor tends to destroy the foundations of the democratic order and its domains of citizenship" (KRUIJT, 2009, p. 14).

This article is about the role of the police in public security reform in the largest country in the region, Brazil. The primary question: is police "politicization" a threat to democracy? While that question will be the focus of much of what follows, the article is part of a broader exercise in thinking about the relationship between the police and democracy in Brazil. This article follows Tilly in seeing that "a regime is democratic to the degree that political relations between the state and its citizens feature broad, equal, protected and mutually binding consultation" (TILLY, 2007, p. 13-14). Democratic regimes have at least two central elements, responsiveness to majorities and the protection of minority rights (O'DONNELL, 1999). Therefore, police politicization can be seen to threaten democracy either as a system of majority rule, and/or as a system for the protection of minority rights.

Why ask whether police politicization threatens democracy on either level described above, and what does it mean? In my research conducted in Brasília, Fortaleza, and Recife, involving interviews with dozens of active duty and former police officers and other state and civil society actors involved in public security reform, the argument that police politicization blocked successful reform of public security came up again and again. (Some scholars make the argument as well, as will be shown later.) What my interlocutors seem to have in mind is the following. Policing has undergone a technological revolution in recent decades. Efficient policing, especially in advanced 
capitalist countries, is seen to involve the collection and circulation of information, the rapid deployment of personnel, scientific investigation of crime scenes and evidence, and the preparation of reports adequate for the prosecution of criminal suspects. However, low salaries and a lack of resources, as well as inadequate training, make this ideal unattainable for the police in Brazil. Instead, poor conditions drive the police to seek extra income in second jobs and, crucially, political patrons who can provide them with protection and perks. Promotion through the ranks is due more to connections to powerful political factions than it is to merit. Furthermore, elected officials are interested in manipulating the police for their own partisan ends. They want to use the police to persecute their political enemies, protect themselves and their political allies, and keep their political machines in office. Furthermore, they peddle short-term and often incoherent crime-fighting solutions to an uninformed electorate, and expect the police to carry out these policies once they are in office. The result is discontinuity, in which each secretary of public security undoes the actions of his predecessors. Policies belong to governments, not to the state. There is no rational, technical allocation of resources, no planning, and no investment in personnel. In appointments at the top of the public security bureaucracy, political loyalty trumps technical ability. Consequently, crime is not adequately prevented or investigated, people feel unsafe, and the police are unfairly blamed for the chaos of public insecurity. Politics reigns, but there is no "policy", in the sense of a rationally-administered, long-term, consistent pursuit of goals by the state. Put another way, the responsiveness of politicians to democratic majorities leads them to interfere in public security and create policing that violates individual (minority) rights, including the right to equality before the law and to security.

This tension between politics and policy is an old theme in political analysis. It tends to be invoked by technically-trained members of the executive branch whenever they feel that their expertise is being compromised by elected officials or popular participation in policy-making. Is this explanation of the failure of public security reform correct? This article argues that it is not. It proceeds in three steps. First, it will contrast two broad approaches to the role of the police in public security reform in Latin America. It shall argue that both of these approaches generate important insights, but neither provides us with the tools to understand the complicated pattern of change and continuity that we find in the region. Second, it will show how organizationally complicated 
and fractured police forces in Brazil are, and how this generates a surprising amount of distrust within the police themselves, as well as between their corporations and other state agencies and civil society groups with whom they are supposed to cooperate. Finally, in the third section, the article will argue that the answer to the main question is both yes and no. Yes, police politicization threatens democracy (understood in its minority-rights protecting dimension) if we have a fairly superficial understanding of politicization; this point will be illustrated with examples. But no, it does not threaten democracy (understood in the same terms) if what is meant by politicization is party control over the executive branch, and consequently the police. This last point is very important, because proposals to "de-politicize" the police in this more fundamental sense are popular in Brazil but contain bigger threats to democracy than the ills that they are supposed to cure. Put another way, calls to insulate the police from democratic majorities in order to make them more respectful of minority rights are misguided, because the political dimension of policing is inescapable (CHEVIGNY, 1995, p. 122-125).

\section{I - Approaches to the Police and Public Security Reform in Latin America}

In the literature on policing and public security reform in Latin America, there is a tension between two contradictory perspectives on the capacity of the police to be democratized, in the sense of becoming more responsive to popular majorities and more respectful of minority rights. The first, which we could call the authoritarian legacies perspective, suggests the impossibility of this goal, and the strong inertial tendencies reinforcing the status quo. The second, which could be labeled the democratization perspective, implies that the goal can be achieved, and this achievement will be aided by long-term developments such as economic globalization, the growth of civil society, and the reform of the state. The discussion that follows concentrates on Brazil, but it would seem that these observations apply to the literature on other countries in the region.

The first approach is grounded in an appreciation of the singularity of Latin American state formation. As Bowman (2002) writes, Latin American militaries preceded independent states, and retained their important role as shapers of internal order throughout 
the $20^{\text {th }}$ century. When examining the state's coercive apparatus in Latin America, what stands out - especially in comparison to Europe - is that militaries spent relatively little time in major inter-state wars, but were instead deployed to fight the "barbarians" within (CENTENO, 2002). What Michael Mann (1993) describes as the civilian "caging" of military power and the separation of military (external defense) and police (internal order) roles, which took place in Western Europe in the $19^{\text {th }}$ century, did not occur in Latin America. Instead, the state's coercive power has been mainly deployed in policing of various kinds (GUTIÉRREZ SANÍN; ACEVEDO; VIATELA; PLATA, 2009), by various state agencies, with the military coming to occupy the apex of a hierarchy to which the police have been subordinate.

Works in this first vein emphasize the historical role of the police in Brazil in disciplining the poor, the marginal, and the oppositional on behalf of the propertied and privileged. Holloway (1993), for example, shows the origins of policing in Rio de Janeiro in the demands of slave-owners for the monitoring and disciplining of their slaves in the city. Pinheiro (1991) depicts the birth of the political police in São Paulo in the 1920s as an outgrowth of employers' concerns about anarchist and Communist activists in the labor movement. Huggins (1998) argues that the reorganization of policing in the 1960s under military rule, including the creation of the Federal Police, was part of a repressive anti-Communist logic fostered and funded throughout the Cold War by the United States. Bicudo (1994) contends that under military rule, the uniformed, patrolling military police were brought under the control of the Army, strengthened and militarized, while the capacity of the plain clothes investigative police was diminished.

Scholars of Brazil's democratic transition have pointed out that while the reform of civil-military relations was a major issue during regime change, the police were left off the agenda, as they were in the rest of Latin America. The notion that authoritarian legacies are responsible for the perpetuation of police violence carries some explanatory weight here, although the definition of legacies can vary from author to author (HITE; CESARINI, 2004). Analysts of the contemporary period argue that increasing civil society participation in public security matters does not necessarily enhance democracy. Writing about public security associations in Mexico City, Davis (2006) argues that they want security at all cost, and justify police violence in the name of efficiency. She also argues that party political competition in Mexico deepens, rather than diminishes, 
police corruption and violence, because the parties manipulate the police in a topdown manner for their own benefit. Scheper-Hughes (2006) asserts that the police in Brazil "cleanse" the public space of the poor and the marginal, thus criminalizing poverty in the pursuit of a sterilized, non-threatening environment for the middle and upper classes. Hinton (2006, p. 224-225) sees at least part of the cause of police violence, corruption, and inefficiency in the police forces' historical role as a tool of social and political repression, and especially as a barrier protecting the rich from the poor.

This work provides us with great insights into the historical role of the police as linchpins of particular kinds of political order, and how the organizational structure and procedures of the police reproduce a violent, repressive, and authoritarian form of policing. However, much of the work does little to explain, concretely, how historical legacies of inequality, exclusion, and repression are reproduced over time (THELEN, 1999, p. 390). Nor does it provide us with tools to understand how policing and public security policies have changed in the quarter century since the democratic transition. Similarly, it does not illuminate how policing in other societies marked by legacies of slavery and high degrees of economic inequality has become - in some instances - somewhat more universalistic, democratic, and accountable than it was. In other words, sometimes legacies are at least partially overcome.

Change is the dominant motif, however, of the other, democratization perspective. Perhaps because problems of the police are so apparent, few scholars make the case for this perspective in wholehearted fashion. Nevertheless, implicit in many works is the assumption that the democratization of the Brazilian state and civil society has finally overtaken the police and other bastions of the public security establishment. The expansion of participation that has transformed city budgeting and decision-making in areas such as public health and education (AVRITZER, 2002, 2009) has begun to influence the police. The creation of new accountability mechanisms that incorporate public participation such as community councils, community policing, and ombudsmen have reoriented the police from the repression of crime to crime prevention, and established the public's right to control or at least influence the state's use of force (see, for example, MACAULAY, 2002). The alleged trade-off between police efficiency, on one hand, and the respect of human rights, on the other, has been discredited. With the entrance of a new generation of former activists (many of them once opponents of the 
military regime, and most of them defenders of human rights) into the state apparatus, a new consensus has emerged that police efficiency and the defense of human rights are thoroughly compatible, equally worthy and equally feasible goals for the police, and the attainment of one will reinforce the achievement of the other.

The argument that public security in Brazil is being democratized could be bolstered by a consideration of the nature of security as a good. More than education and health, security has the characteristics of a public, or at least a club good. However much the wealthy hide within fortress-like apartment buildings, helicopters, and bullet-proof cars, they still have to traverse public spaces from time to time, and cannot completely immunize themselves from violent crime. Furthermore, fear of crime erodes the well-being of even those most protected by private security, further motivating the powerful to action. Actors within the political system therefore have incentives to produce solutions to the public security dilemma, enhancing the possibilities of new policies that garner the support of democratic majorities.

Works that share the democratization framework, like those in the authoritarian legacies perspective, contribute richly to our understanding of policing in Brazil's political system. However, they suffer from a limitation that is the opposite of that of the authoritarian legacies approach. While they help us to understand why and how reform might take place, they offer fewer insights into resistance to and failure of reform, and the mechanisms that might preserve the status quo in some cases. What is needed are theoretical approaches that stand mid-way between the key assumptions of each of these perspectives, and that generate hypotheses about what and who have driven public security reforms in Brazil, what the results of these reforms efforts were, and why those outcomes occurred.

Some might object that this depiction of the literature as torn between two irreconcilable poles, one emphasizing historical continuity and the authoritarian nature of the police, and the other change and the gradual democratization of policing, is a gross caricature. However, many works gravitate strongly towards one or another of these perspectives, even though some work is highly nuanced, making arguments about why some aspects of reform have produced meaningful change, while others have not. Often lacking are clear theoretical guideposts as to what produces change and variation in policing in Brazil and Latin America. 
Other subfields provide glimpses of the kind of theoretical clarity that appears to be missing from the literature on Latin American policing. In the subfield of comparative judicial politics, to take one example, a thesis about the "judicialization" of politics has served as a lightening-rod for debate. This thesis is that in more and more countries, courts have come to be relied upon to resolve conflicts that were once the purview of legislatures or the executive branch. According to a leading advocate of this approach, Ran Hirschl, the judicialization of politics is driven by threatened elites attempting to maintain their dominance over oppositional movements. Conservative elites are thus sometimes able to insulate political issues from popular input by removing them to courts, where these elites have more control (HIRSCHL, 2000; TATE, 2007). Regardless of the robustness of this argument, the comparative judicial politics subfield contains at least one "big picture" explanation that can account for both change and continuity in the relationship between courts and other parts of the state apparatus.

Another example comes from the subfield of comparative political economy. In the latter area, scholars have debated a "globalization" thesis that contends that economic globalization, or the increasing transnational integration of markets, has caused countries to converge upon a liberal, Anglo-American economic model with a limited welfare state and heavy constraints on state intervention in the market (VAIL, 2010, p. 4). While the globalization thesis has lost some of its luster in the wake of the 2008-2009 credit crisis and recession, what is important is that the subfield benefits from a clear, important hypothesis that researchers can confirm or refute.

Such hypotheses seem to be missing in the subfield of police and public security reform in Brazil and Latin America. Waquant (2006) provides a possible contender when he identifies a global tendency for governments to dismantle welfare safety nets while making criminal justice more punitive and expanding prisons, such that the welfare state is being gradually replaced by the "carceral state". But this argument does not fit Latin America, where social spending and prison populations are rising together. Most researchers who grapple with specific cases of reform, therefore seem to be left with ad hoc explanations that veer between the authoritarian legacies and democratization perspectives. For example, Ungar (2009, p. 22-74), in an otherwise astute analysis, lists ten obstacles to public security reform, but does not offer an account of why what he calls the "citizen security crisis" is worse in some parts of Latin America than others. In 
addition to historical legacies, Hinton's well-researched contribution (2009, p. 223) identifies "personalistic and partisan patterns of police governance and symbolic initiatives" and deficits in democratic accountability and "checks and balances" at all levels of the state as the reasons for the failure of public security reform in Brazil, again without focusing on variation in outcomes within the country and across countries, or why these legacies, patterns, and deficits seem to have been partially overcome in some places.

Hinton's explanation is particularly problematic because it seems to be based on an implicit dichotomy between democratically formulated, universalistic, nonviolent, uncorrupt, and efficient policing in the "first world" - reflecting a political system with the same qualities - and its opposite in Brazil. Hinton (2009, p. 230) describes a Brazilian "political game" or "enduring ethos permeating national life" characterized by "tolerance for corruption, low levels of public accountability, and intense, destructive, and protracted political contests" resulting in "particularistic, venal, or elite-interest capture of public policy, such that the government fails to respond appropriately to the needs of the majority population". This is a sui generis explanation that does not identify anything that is uniquely Brazilian. The description applies to political life in a great many countries. Furthermore, Hinton's (2009, p. 230) identification of the lack of "checks and balances" in the Brazilian state seems based (again implicitly) on the assumption that such checks and balances are flourishing elsewhere. However, at least in the Anglo-American world, they are not. Many observers of politics in the USA and UK, for example, have pointed out how the "imperial presidency" in the former and the "presidential prime ministership" in the latter reflect an executive that is no longer checked and balanced in a way that would be recognized by $18^{\text {th }}$ century constitutionalists (see, for example, BACEVICH, 2008, p. 67-71 and AGAMBEN, 2005). If Montesquieu is dead in the "first world", then his absence in Brazil hardly counts as a convincing explanation of the distinctiveness of policing there.

Perhaps the standoff between the authoritarian legacies and democratization perspectives is due, in part, to a tendency to compare Brazilian policing with some idealized norm. Holston (2008, p. 14), in defense of his own approach to what he calls "insurgent citizenship," makes an eloquent plea for avoiding such dichotomization:

[...] although Brazil's democratization has not been able to overcome these problems [of violent reactions to reform in defense of old paradigms of order], neither 
have the counterconfigurations of violence and injustice been able to prevent the development of significant measures of democratic innovation. Above all, they have not prevented the widespread legitimation of an insurgent democratic citizenship...। describe Brazil's case in these terms not to brand it as pathological or deviant from some supposed norm. This kind of evaluation thrives among both Brazilian and international critics because all too often they understand citizenship, democracy, rule of law, and modernity itself as original formulations of European and North American experience. In that register, these notions can only seem incomplete, pathetic, derivative, or failed when grafted onto countries with different histories and cultures. To the contrary, my work on Brazil leads me to see them as assemblages of the modern that have circulated around the world for centuries and that people engage with variously depending on their circumstances [...].

Greater effort to understand what Brazilian public security policy is (rather than what it is not) might result in progress in the subfield. What seems to be lacking at present are convincing hypotheses about both change and variation in policies, and their outcomes. As Fiona Macaulay (2007, p. 627) writes, "We [...] need many more finely-grained analyses of the dynamics of reform efforts and of the policy environments in which these take place in order to understand how and why reform initiatives are often derailed or subverted and, more rarely, flourish and can be embedded or replicated." In particular, analysts must confront tensions between the majoritarian and minority rights-protecting elements of democracy, identified earlier, and potential contradictions between the professional and political demands on the police.

\section{II - Policing as a Coordination Problem}

Trust is crucial to the functioning of democratic institutions (ROTHSTEIN, 2005). Citizens in a democracy are more likely to obey the law and cooperate with the police if they have some degree of trust in the police as an institution. Similarly, state agents in the public security system are more likely to cooperate with one another if they trust their counterparts in other agencies.

However, levels of public trust in the police in Latin America are low. Brazil is no exception to this generalization. According to one survey published in June 2007, only 24 percent of Brazilians reported trust in the police, compared to an average of 30 percent for Latin America as a whole (Consortio Iberoamericano de Investigacion de Mercados 
y Asesoriamento, 2009). This is due, in part, to widespread police abuse of members of the public, especially the poor, as well as the reputation of the police for corruption and inefficiency. Another survey conducted in 2009 found that 6.3 percent of Brazilians reported having been abused by the police in the previous twelve months. This placed Brazil in the top third of the twenty Latin American countries where the poll was carried out (CRUZ, 2009, p. 1). A steady outpouring of denunciations by human rights groups, as well as journalistic coverage and cinematic treatment, has made this problem widely-known.

Less well-known is the low level of trust within and between the police forces themselves (see Figure 1). This lack of trust and failure to cooperate take many forms. Within the military police, for example, there is a wide gulf between the relatively wellpaid and highly educated officer corps, on the one hand, and the badly-paid, undereducated, poorly-trained, and often badly-treated lower ranks (private to sergeant) or praças. One military police colonel described the relationship between enlisted men and officers in his corporation as one of medieval "vassalage":

We have a serious problem of personal relations within the corporation [military police] even today, in which the officers, many of them, treat the enlisted men badly... I think this is related to social class, the idea that the officer is a prince, and the enlisted man a plebian. There is this relationship of vassalage. It is not a relationship of leadership. I don't see you as a professional, I see you as a pawn who has to obey my orders. We have an authoritarian culture, and we don't yet understand that, in order to gain respect, I have to be a leader above everything else. (Interview with military police colonel, Recife, Pernambuco, 24 April 2006; transcript translated by the author.)

The creation of enlisted men's associations, fueled in part by officers' abuse of their privileges and mistreatment of lower-ranking personnel, has been a significant development in the politics of policing in Brazil during the last fifteen years. The police strikes of 1997, which began in Minas Gerais and spread to nine other states, are an example of this cleavage within the military police. The police strikes were triggered by a decision of the Governor of Minas Gerais to increase only the pay of military police officers, and not that of their subordinates, thus widening an already-considerable salary gap. Since 1997, police strikes (especially of the civil police) have been limited to individual states, but are common. 
In the investigative civil police, the divide between delegados, investigators who are supposed to be trained in the law and agentes, who are not, is not quite as fixed as that between officers and praças in the military police, because some agentes are able to study law and become delegados. (In addition, REAMES, 2005, p. 41, found that nationally, only 60 percent of delegados actually have a law degree.) But the divide is still pronounced, and the distrust of police personnel at the level of the station for those managing the upper echelons of the system is considerable.

Perhaps the most serious gap in trust for everyday policing is that between the uniformed military police and the plain-clothes civil police. Disputes between and failures of cooperation of the two forces, which are generally not deployed within common territorial limits, are numerous. To give one example, the radio frequencies used by the two forces are not the same in most states. The military police, who make the bulk of arrests on the street, are sometimes reluctant to take suspects to civil police stations for processing. Fearing that their suspects will not be charged, they administer their own form of direct corporal punishment to suspects. In the worst cases, this means summary execution. Some forms of police violence are thus linked to the military police's mistrust of the civil police and the judiciary.

Inter-police mistrust finds its counterpart in mistrust within the entire public security bureaucracy and affiliated organizations, involving elected officials, state Secretariats of Public Security (in some states called Secretariats of Social Defense), the police forces, the Federal government, municipal governments, prosecutors, judges, the prison system, state social assistance agencies, the media, and non-governmental organizations. In this sense, reform of policing and public security policy involves very difficult attempts to coordinate organizations that have a strong tendency to dig in to defensive positions in which they hoard information, zealously guard the boundaries of their own jurisdiction, claim distinctive corporate privileges, both legal and informal, and blame outside agencies for public security problems. At its worst, public security policy in Brazil resembles a war of each against all, in which common policies and interests are hard to discern, and in which all parties seem to be locked in a downward spiral of steadily worsening patterns of violent crime by both state and non-state organizations (see Figure 1). 
Figure 1: Examples of Mistrust Within the Public Security Bureaucracy

(Based on nine interviews conducted in Recife, Pernambuco between 2006 and 2008)

\begin{tabular}{|c|c|c|}
\hline Official & Object of mistrust & Reason for mistrust \\
\hline $\begin{array}{l}\text { Secretariat of Social } \\
\text { Defense official }\end{array}$ & Politicians & $\begin{array}{l}\text { They have no technical knowledge of public security issues, but } \\
\text { make outlandish promises. }\end{array}$ \\
\hline Civil Police agent & Military Police & $\begin{array}{l}\text { They are more politically connected and favored than are the Civil } \\
\text { Police. }\end{array}$ \\
\hline Civil Police agent & $\begin{array}{l}\text { Secretariat of Social } \\
\text { Defense officials }\end{array}$ & $\begin{array}{l}\text { They do not share crime data with Civil Police agents in stations. } \\
\text { They do not provide incentives for the Civil Police to solve crimes. }\end{array}$ \\
\hline Civil Police agent & $\begin{array}{l}\text { Secretariat of Social } \\
\text { Defense/State } \\
\text { Governor }\end{array}$ & $\begin{array}{l}\text { They promote Civil Police personnel on the basis of political loyalty, } \\
\text { not merit. }\end{array}$ \\
\hline $\begin{array}{l}\text { Military Police } \\
\text { colonel }\end{array}$ & Federal government & $\begin{array}{l}\text { It is absent in the area of public security. It plans to use the Força } \\
\text { Nacional (a composite police force made up of officers from various } \\
\text { states) to break police strikes in the states. }\end{array}$ \\
\hline $\begin{array}{l}\text { Military Police } \\
\text { colonel }\end{array}$ & Judges & $\begin{array}{l}\text { Due to their huge backlog of cases, they are selective in their } \\
\text { treatment of crime. This makes them appear arbitrary. }\end{array}$ \\
\hline $\begin{array}{l}\text { Military Police } \\
\text { colonel }\end{array}$ & Civil Police & $\begin{array}{l}\text { Due to their huge backlog of cases, they are selective in their } \\
\text { investigation of crime. They respond to pressure from the rich and } \\
\text { powerful in their investigations. Most have second jobs, and many } \\
\text { are corrupt. }\end{array}$ \\
\hline $\begin{array}{l}\text { Military Police } \\
\text { colonel }\end{array}$ & Prison officials & $\begin{array}{l}\text { They degrade prisoners and make them more hateful and violent, } \\
\text { creating problems when they are released. }\end{array}$ \\
\hline $\begin{array}{l}\text { Former Secretary of } \\
\text { Social Defense }\end{array}$ & The media & $\begin{array}{l}\text { They blame the police for all the problems of public security. They } \\
\text { emphasize the negative, but not the positive. }\end{array}$ \\
\hline $\begin{array}{l}\text { Former Secretary of } \\
\text { Social Defense }\end{array}$ & The middle class & They buy drugs and sustain trafficking. \\
\hline Official & Object of Mistrust & Reason for Mistrust \\
\hline $\begin{array}{l}\text { Former Civil Police } \\
\text { delegado }\end{array}$ & $\begin{array}{l}\text { Secretariat of Social } \\
\text { Defense officials }\end{array}$ & They (illegally) profit from their involvement in private security firms. \\
\hline $\begin{array}{l}\text { President of } \\
\text { the Civil Police } \\
\text { Association }\end{array}$ & Judges & They are excessively well-paid, and are not accountable to anyone. \\
\hline $\begin{array}{l}\text { President of } \\
\text { the Civil Police } \\
\text { Association }\end{array}$ & $\begin{array}{l}\text { The city } \\
\text { government. }\end{array}$ & $\begin{array}{l}\text { It wants to protect tourists, but is less concerned with protecting the } \\
\text { poor. }\end{array}$ \\
\hline $\begin{array}{l}\text { Civil Police } \\
\text { delegado }\end{array}$ & Military Police & $\begin{array}{l}\text { Like the military, they are trained to kill their enemies, not police } \\
\text { citizens. They are favored with heavy weapons and special training, } \\
\text { and want to dominate public security policy-making. }\end{array}$ \\
\hline $\begin{array}{l}\text { Civil Police } \\
\text { delegado }\end{array}$ & Prosecutors & $\begin{array}{l}\text { They violate the law by insisting on receiving inqueritos (police } \\
\text { reports) before judges. }\end{array}$ \\
\hline $\begin{array}{l}\text { Civil Police } \\
\text { delegado }\end{array}$ & Elected officials & $\begin{array}{l}\text { They interfere with police work by pressuring the Governor to } \\
\text { transfer capable police investigators, in order to protect their allies. }\end{array}$ \\
\hline $\begin{array}{l}\text { State Attorney } \\
\text { General }\end{array}$ & The Army & $\begin{array}{l}\text { It still wants to exercise tutelage over the judiciary, as it did during } \\
\text { the military dictatorship. }\end{array}$ \\
\hline $\begin{array}{l}\text { State Attorney } \\
\text { General }\end{array}$ & Police & $\begin{array}{l}\text { They resist genuine external control; they have cooperated in the } \\
\text { creation of a Police Ombudsman, but only because the ombudsman } \\
\text { relies on police internal affairs for investigations. }\end{array}$ \\
\hline $\begin{array}{l}\text { State Attorney } \\
\text { General }\end{array}$ & Prison officials & $\begin{array}{l}\text { They preside over a system in which a large proportion of prisoners } \\
\text { have not been judged in court, but remain in prison. }\end{array}$ \\
\hline
\end{tabular}

Note: Repetition of the title of the official indicates the same person. In many interviews, the same objects of mistrust were identified; for purposes of clarity, these have been attributed to only one interviewee, and not repeated. 
Inter-agency mistrust and failure to cooperate in Brazilian public security is a good example of what Douglass North calls "incentive structure or coordination effects" "once a set of institutions is in place, actors adapt their strategies in ways that reflect but also reinforce the 'logic' of the system (quoted in THELEN, 1999, p. 392). Institutions "reflect, and also reproduce and magnify, particular patterns of power distribution in politics"; they are "feedback mechanisms at both the ideational and the structural levels" (THELEN, 1999, p. 394). Such feedback mechanisms are difficult to analyze because "institutions are embedded in a context that is constantly changing, [and] stability - far from being automatic - may have to be sustained politically (THELEN, 1999, p. 396).

It is within these networks of mistrust and non-cooperation that we must place the issue of police "politicization". A certain kind of police politicization - membership in networks of mutual support and patronage, centered around particular political candidates and office holders within political parties and alliances of political parties - is criticized by members of both the civil and military police. Academic observers echo these complaints. For example, Ungar (2009, p. 69) decries "politicized promotion" within the police that "helps perpetuate bad management". And Hinton (2009, p. 227) writes, "For now, police governance remains ad hoc and consists primarily in the appointment of a police chief by local state governors. Appointments are made for partisan and particularistic reasons and rarely are based on professional benchmarks."

Such assertions are misleading. An increasing number of state governors are appointing ex-members of the Federal Police to head their Secretariats of Public Security, in part because of the growing prestige of the Federal Police and its reputation for technical competence. State governors have strong incentives to demand both political loyalty and technical competence from their appointees, especially since the perception of bad management of the public security apparatus is likely to be costly in electoral terms. And while complaints about non-meritocratic promotion and non-universalistic provision of police services are plausible, they often spill over into a much broader critique of political parties' control of the public security apparatus. This latter critique threatens to produce "solutions" to the problems of insecurity and violence that might be worse than the status quo. The next section will discuss this claim in greater detail. 


\section{III - Why "Politicization" is not Really the Problem}

If police "politicization" is defined narrowly, then its anti-democratic character becomes clear. For example, if police politicization is understood to mean the covert alliance between top police officials with elected officials and owners of businesses - as on the board of a private security company - then it seems plausible that those police officials will substitute narrow private interests for a broader, more public interest in the exercise of their duties. Similarly, if police politicization includes the practice of police officers working second jobs for private businesses, or of police officials raising money from people in their districts to use for their campaigns for elected office without declaring those contributions to the electoral authorities, then the problem it poses for broadly-based, legitimately-implemented public security policy is apparent. They are anti-democratic because they inhibit the formulation and implementation of policy for the benefit of the majority, and cloak the manipulation of power for private interests behind a democratic façade.

However, all of the examples given above are illegal in Brazil. In fact, the arguments about police politicization are often made in a much broader fashion to include any political interference with the technical business of policing. It is these argument that are more difficult to accept, and at least potentially problematic.

For example, while the complaint by the police that their promotions and deployment are subject to illegitimate political interference has some merit, it obscures an important point. This complaint stems in part from the envy of the police for other professionals in the criminal justice system with whom they have to deal, especially judges and prosecutors. Both judges and prosecutors have more status and are paid much more than the police, and enjoy irremovability - they cannot be arbitrarily transferred by elected officials. As members of the judiciary (in the judges' case) and a "fourth branch" of the state (in the case of the prosecutors, members of the Public Ministry), these professionals are not subject to the kinds of direct political pressures that the police encounter.

The police, for their part, are members of the executive branch. Their ability to successfully enact reforms depends in great measure on the perceived legitimacy of their actions, and so it is entirely appropriate that they are ultimately subject to some political 
control. Policing is at bottom a political, rather than a purely technical, activity, as the etymology of police and politics shows (both words spring from the Greek root polis, or city). The precise manner in which the police are subject to political control varies across political systems, but there is no evidence that a system that maximizes insulation from party politics (such as the British system of police authorities, recently abolished, which appointed chief constables and were made up of appointed representatives of different political parties) is inherently more legitimate - or efficient - than one that puts the police directly under the control of an elected official such as a mayor (as in U.S. cities). Because enhanced legitimacy is a major goal of many public security reforms, the conformity of such arrangements to popular conceptions of good governance will determine their relevance to any given situation. Arguments that posit the universal superiority of abstract institutional designs are not persuasive when it comes to the implementation of policies - such as those in public security - that are heavily dependent on popular support and cooperation.

Examination of apparently successful public security reforms reveals the importance of electoral politics to their formulation and implementation. The much-touted "zero tolerance" policies of the New York Police Department in the 1990s, which many Latin American public security officials claimed to emulate, were partly an outcome of Mayor Rudy Giuliani's political ambitions. (Giuliani was Mayor of New York City from 1994 to 2001). In fact, Giuliani eventually fired the main architect of the reforms, Police Commissioner William Bratton, when Bratton threatened to garner more attention and credit for the policies than Giuliani himself. In Giuliani's run for president in 2008, he attempted to use his public security record as mayor to attract voters.

Perhaps more relevant to Brazil is the case of Bogotá, Colombia. In Bogotá, Colombia, the homicide rate fell from around 80 per 100,000 in 1993 to 21 in 2004. Some analysts attribute this drop to an integrated municipal program that included public health interventions, the reclaiming of public space, criminal justice reform, the improvement of crime and violence information systems, control of public alcohol consumption, and assistance to "at-risk" youth (SOARES; NARITOMI, 2007, p. 23). Another aspect of the reforms was the creation of local security fronts involving members of the community and the police (MONCADA, 2009). Key to implementing the program was Antanas Mockus, mayor of Bogotá in 1995-1996 and again in 2001-2003. Mockus ran unsuccessfully for 
the presidency in 1998, and his zeal for municipal reform seems to have been fuelled, at least in part, by his wider political ambitions (CABALLERO, 2004).

In Brazil, the link between the ambitions of elected officials and parties and successful public security reform can also be seen clearly. In Fortaleza, Ceará, for example, the municipal guards were expanded in the 2000s and transformed into an educative, preventive police force that works closely with the military police as a front-line public security organization. The reform was largely the work of the PC do B (Communist Party of Brazil) and PT (Workers' Party) mayors in office during that period. Similarly, intentional homicides in the city of São Paulo, Brazil fell by almost 70 percent from 1999 to 2006. Policies that had been previously introduced included dry-laws (the early closing of bars), voluntary disarmament initiatives, social programs, increased incarceration, and reforms in police organization and procedures (SOARES; NARITOMI, 2007, p. 23). These reforms were enacted by mayors from the PSDB (Social Democratic Party) and figured strongly in the PSDB's burnishing of its image as a responsible, serious contender for control of the Federal executive. Finally, reforms in Diadema, in the state of São Paulo, have been closely watched and partially emulated throughout Brazil, because (as in the city of São Paulo) they seemed to be at least partially responsible for a marked drop in homicides. The Diadama programs were the outgrowth of cooperation between the municipal government, controlled by the PT, civil society organizations, and the police.

All of these reforms involve movement from what North, Wallis, and Weingast (2009) would call "natural states" towards "open access societies". The core difference between these two types of societies is how they control violence. In natural states, "Access to violence is open to anyone strong enough and well-organized enough to use it. The natural state coordinates these individuals and groups through an interlocking set of rent-creating arrangements that limit access throughout the rest of society" (NORTH; WALLIS; WEINGAST, 2009, p. 121). The political management of violence is based on "the manipulation of economic privileges" (NORTH; WALLIS; WEINGAST, 2009, p. 122). Open access societies, in contrast, (despite the label) limit access to the means of coercion, and thus violence, more strictly, and base the management of violence on impersonal rules and organizations. Formal institutions, including the judiciary, embody agreements about how and when violence can legitimately be used, and hem in specialized military and police forces. These institutions and agreements regulate the formal authority 
granted to the military and police to intervene in private interactions. According to North and his collaborators, "The resulting rules governing the use of violence in open access orders must be impersonal; that is, the agreements must be independent of the identity of the individual member of the military or police force and, equally important, independent of the identity of the political officials. If the rules do not apply impersonally, the society is a natural state" (NORTH; WALLIS; WEINGAST, 2009, p. 121).

For North, Wallis, and Weingast, the transition from a natural state to an open access society involves the attainment of three conditions: the rule of law for elites; the recognition of "perpetually-lived organizations" (such as corporations) in the public and private spheres, and the "consolidated" control of the military (NORTH; WALLIS; WEINGAST, 2009, p. 151). This last condition, the most difficult to achieve in their judgment, means that "nonmilitary elite groups and organizations must be capable of disciplining the military force through nonmilitary means" (NORTH; WALLIS; WEINGAST, 2009, p. 170).

The idea of an open access society is clearly an ideal-type that real societies can only approximate. It seems commonplace and perhaps inevitable that public security policy, even when it is supported by a large majority, will still exclude and repress minorities in the population. Nevertheless, progress towards what Rothstein (1998, p. 26) calls "universal" policies marked by "uniform, standardized solutions" is possible. However, the important point to make in this context is that the deployment of an "apolitical", legal-rational bureaucracy is not the only, or indeed the best, way to implement such policies (ROTHSTEIN, 1998, p. 108-115). As Rothstein shows, the Swedish welfare state, based heavily on universal policies, was implemented in a variety of ways, and was created by successive governments of a specific party, the Social Democrats.

Rather than decry party "politicization" in public security, what we need is a better understanding of the mechanisms by which party competition stimulates the enactment of more universal, "open access" types of public security policy, and when it produces results that push in the opposite direction. The theoretical literature is mixed, and there seems to be no a priori reason to assume that party competition necessarily will - or will not - produce better public security policy. Two recent pieces of work provide some promising insights in this regard. Reames (2005, p. 35) suggests that successful police reform in Brazil depends primarily on "civil society networks, the existence of political entrepreneurs, and the strategies used" rather than high levels of socioeconomic 
development or proximity to other states where reforms have been successful. In a similar vein, Gutiérrez-Sanin, Acevedo, Viatela, and Plata $(2009$, p. 1) attempt to explain the failure, in Colombia from 1930 to 1946, of police "statization" (defined as "the ability of the state to provide security through a set of increasingly bureaucratized agencies placed in a chain of command and thus a) not obeying directly private agents, and taking only explicitly and formally regulated private security demands; [and] b) acting according to relatively universal (formal, bureaucratic) principles". In a fascinating paper, they show how party competition between Liberals and Conservatives turned both parties against statization; statization "impaired the capacity of the subnational caucuses to mobilize people against adversaries, including inter-party ones...the police continued to be a crucial instrument for political competition, and the regions would not allow easily the center to take control of them" (GUTIÉRREZ-SANIN; ACEVEDO; VIATELA; PLATA, 2009, p. 26-27).

The Colombian example of party competition reinforcing non-universalistic policing helps explain why anti-political solutions to the public security dilemma can be so tempting to so many. An example of this in Brazil is the popular film Tropa de Elite (2007) and the book on which it is based, Elite da Tropa (SOARES; BATISTA; PIMENTEL, 2005). Two of the book's authors had been members of the BOPE (Batalhão de Operações Policiais Especiais, Police Special Operations Battalion), a special unit of the military police of Rio de Janeiro. (At the time of the book's publication, one author was an ex-member of BOPE, while the other was still in the corporation.) In the film, middle-class university students working for NGOs in favelas are depicted as witless pawns of drug traffickers. In the book, Rio's Governor and Secretary of Public Security are depicted as duplicitous hypocrites, eager to deploy violence in the favelas, but just as ardent in denying any responsibility for the carnage that their own orders produce. The message seems to be that politics, in various forms, is interfering with the self-sacrificing heroes in the BOPE, who stand between ordinary citizens and the drug traffickers. The BOPE, however, has a military orientation towards crime - its personnel are trained to fight a war, and the battalion's emblem is a human skull penetrated by a knife. A more graphic symbol of the dangers of an anti-political orientation towards public security can hardly be imagined. 


\section{Conclusion}

This article questions the relationship between the police and democracy, and asks how we can explain the results of the bewildering varieties of police reform that have been attempted in Brazil during the last fifteen years. The arguments made here are largely negative, refuting or at least refining an inference that can be found in the literature on policing. This is the idea that the main problem of public security in Brazil is the "politicization" of the police. The politicization thesis is correct in the narrow sense that political considerations are too dominant in some instances of police management. This article contains examples that show the extent to which this criticism is valid. But in a more profound sense the politicization argument is misleading, because it implies that the police should be insulated from democratic majorities in order to more effectively protect minority rights. However, as this article has shown, many successful reforms have been led by elected politicians and political parties for electoral reasons. Rather than invalidate them, the party political direction of the reforms helped to make them successful. The problem is not party political competition per se, but forms of party political competition that block innovation and reform. We still don't know enough about what these are, and how they differ from forms of party political competition that are conducive to the democratization and increased efficiency of the police.

\section{References}

Agamben, Giorgio (2005) State of Exception. Chicago: University of Chicago Press.

Avritzer, Leonardo (2002) Democracy and the Public Sphere in Latin America. Princeton: Princeton University Press.

Avritzer, Leonardo (2009) Participatory Institutions in Democratic Brazil. Washington D.C.: unpublished manuscript, Woodrow Wilson Center.

Bacevich, Andrew (2008) The Limits of Power: The End of American Exceptionalism. New York: Metropolitan Books.

Bicudo, Hélio (1994) Violência: O Brasil Cruel e Sem Maquiagem. São Paulo: Editora Moderna.

Bowman, Kirk (2002) Militarization, Democracy, and Development: The Perils of Praetorianism in Latin America (University Park, PA: Pennsylvania State University Press). 
Caballero, Marina Cristina (2004) "Academic turns city into a social experiment" in Harvard Gazette March 11, accessed online on 1 September 2009 at http://www.news.harvard. edu/gazette/2004/03.11?01-mockus.html

Centeno, Miguel (2002) Blood and Debt: War and the Nation-State in Latin America. University Park: Pennsylvania State University Press.

Chevigny, Paul (1995) Edge of the Knife: Police Violence in the Americas. New York: The New Press.

Consortio Iberoamericano de Investigacion de Mercados y Asesoriamento (2009), "Accountability Amongst Brazil's Police" in Latin American Thought at http://latamt hought.org/2009/03/24/accountability-amongst-brazils-police accessed on 24 August 2009.

Cruz, José Miguel (2009) "Police Abuse in Latin America" in AmericasBarometer Insights, Number 11, p. 1.

Davis, Diane (2006) "Undermining the Rule of Law: Democratisation and the Dark Side of Police Reform in Mexico" in Latin American Politics and Society, Volume 48, Number 1 , Spring, pp. 55-86.

Gutiérrez-Sanin, Francisco, Tatiana Acevedo, Juan Manuel Viatela, and Camilo Plata (2009) Police and State during the Liberal Republic (Colombia: 1930-1946). Bogotá: unpublished paper, Instituto de Estudios Políticos y Relaciones Internacionales, Universidad Nacional de Colombia.

Hinton, Mercedes (2009) "Police and State Reform in Brazil: Bad apple or Rotten Barrel?" in Mercedes Hinton and Tim Newburn, eds. Policing Developing Democracies. London: Routledge.

Hinton, Mercedes (2006) The State on the Streets: Police and Politics in Argentina and Brazil. Boulder: Lynne Rienner.

Hirschl,Ran(2000)"ThePolitical Origins of JudicialEmpowerment through Constitutionalization: Lessons from Four Constitutional Revolutions" in Law and Social Inquiry, Volume 25, Number 1, Winter, pp. 91-149.

Hite, Katherine and Cesarini, Paola (2004) Authoritarian Legacies and Democracy in Latin America and Southern Europe. Notre Dame, IN: University of Notre Dame Press.

Holloway, Thomas (1993) Policing Rio: Repression and Resistance in a Nineteenth-Century City. Stanford: Stanford University Press. 
Holston, James (2008) Insurgent Citizenship: Disjunctions of Democracy and Modernity in Brazil. Princeton: Princeton University Press.

Huggins, Martha (1998) Political Policing: The U.S. and Latin America. Durham: Duke University Press.

Kruijt, Dirk (2009) Civil and uncivil actors in the Latin American urban domain. Potsdam: Paper prepared for presentation at the ECPR General Conference, 12 September 2009.

Macaulay, Fiona (2007) "Knowledge Production, Framing and Criminal Justice Reform in Latin America" in Journal of Latin American Studies, Volume 39, 2007, pp. 627-651.

Macaulay, Fiona (2002) Problems of Police Oversight in Brazil. Oxford: University of Oxford Centre for Brazilian Studies, Working Paper 33-02.

Mann, Michael (1993) The Sources of Social Power, Volume ll: The rise of classes and nation-states, 1760-1914. Cambridge: Cambridge University Press.

Moncada, Eduardo (2009) "Towards Democratic Policing in Colombia?: Institutional Accountability through Lateral Reform" in Comparative Politics, July.

North, Douglass, John Wallis and Barry Weingast (2009) Violence and Social Orders: A Conceptual Framework for Interpreting Recorded Human History. Cambridge: Cambridge University Press.

O’Donnell, Guillermo. Teoria democrática e política comparada. Dados [online]. 1999, vol.42, n.4 [cited 2012-07-18], pp. 655-690 . Available from: <http://www.scielo.br/scielo. php?script=sci_arttext\&pid=S0011-52581999000400001\&lng=en\&nrm=iso > .

ISSN 0011-5258. http://dx.doi.org/10.1590/S0011-52581999000400001.

O'Donnell, Guillermo, Jorge Vargas Cullel, and Osvaldo lazzetta, eds. (2004) The Quality of Democracy: Theory and Applications. Notre Dame: Notre Dame University Press.

Pinheiro, Paulo Sérgio (1991) Estratégias da llusão: A Revolução Mundial e o Brasil 1922-1935. São Paulo: Companhia das Letras.

Reames, Benjamin (2005) Democratic Police in Brazil? Civil Society Repertoires and Decentralized Reforms. New York: unpublished manuscript.

Rothstein, Bo (1998) Just Institutions Matter: The Moral and Political Logic of the Universal Welfare State. Cambridge: Cambridge University Press.

Rothstein, Bo (2005) Social Traps and the Problem of Trust. Cambridge: Cambridge University Press. 
Scheper-Hughes, Nancy (2006) "Death Squads and Democracy in Northeast Brazil" in Jean Comaroff and John Comaroff, eds. Law and Disorder in the Postcolony (Chicago: University of Chicago Press), pp. 150-187.

Soares, Luiz Eduardo, André Batista and Rodrigo Pimentel (2005) Elite da Tropa. Rio de Janeiro: Editora Objetiva.

Soares, Rodrigo and Joana Naritomi (2007) Understanding High Crime Rates in Latin America: The Role of Social and Policy Factors (Cambridge: Paper prepared for the conference "Confronting Crime and Violence in Latin America: Crafting a Public Policy Agenda", John F. Kennedy School of Government, Harvard University, July).

Tate, C. Neale (2007) The Literature of Comparative Judicial Politics: A 118 Year Survey. Fukuoka, Japan: Paper presented at the 20th World Congress of the International Political Science Association, 10 July, 2006 and revised 13 December 2007.

Thelen, Kathleen (1999) "Historical Institutionalism in Comparative Politics" in the American Review of Political Science, Volume 2, pp. 369-404.

Tilly, Charles (2007) Democracy. Cambridge: Cambridge University Press.

Ungar, Mark (2009) Policing Democracy: Overcoming Obstacles to Citizen Security in Latin America. Washington D.C.: unpublished manuscript, Woodrow Wilson Center.

Vail, Mark (2010) Recasting Welfare Capitalism: Economic Readjustment in France and Germany. Philadelphia: Temple University Press.

Wacquant, Loïc (2006) Punishing the Poor: The New Government of Social Insecurity. Durham: Duke University Press, forthcoming in 2006, accessed at http://www.ksg.harvard.edu/ inequality/Seminar/Papers/Wacquant05.pdf on February 15, 2007.

Recebido: 04/04/2014

Aceito: 02/08/2014 